\title{
Community Pharmacy Use by Children across Europe: A Narrative Literature Review
}

\author{
Mitch Blair ${ }^{1}$ and Arjun Menon ${ }^{2, *}$ (1) \\ 1 Department of Paediatrics, Imperial College London, London SW7 2AZ, UK; m.blair@imperial.ac.uk \\ 2 Imperial College School of Medicine, Imperial College London, London SW7 2AZ, UK \\ * Correspondence: arjun.menon13@imperial.ac.uk; Tel.: +44-7742149477
}

Received: 5 April 2018; Accepted: 30 May 2018; Published: 4 June 2018

\begin{abstract}
The use of community pharmacies across Europe has potential to alleviate the burden on overstretched healthcare providers. Children and young people (0-18 years) account for a large number of primary care attendances. This narrative literature review between January 2000 and December 2017 examines the use of community pharmacy by paediatric patients in Europe. The results report both positive and negative perceptions of community pharmacy by parents and children, opportunities for an extended role in Europe, as well as the need for further training. The main limitations were the inclusion of English language papers only and an initial review of the literature carried out by a single researcher. It remains to be seen whether a 'new-look' role of the community pharmacist is practical and in alignment with specific European Commission and national policies.
\end{abstract}

Keywords: community pharmacy; pharmacist; children; parent; Europe

\section{Introduction}

Community pharmacy is a field of primary care medicine, which serves a large proportion of the European population. As of 2016, there were an estimated 400,000 community pharmacists in Europe visited by 46 million citizens daily [1,2], representing almost $10 \%$ of the 508 million people living in the European Union (EU) [3]. In general, the core pharmacy services across the EU include dispensing medication, medication management, emergency care (e.g., emergency contraception), as well as minor ailment management [1,2]. An example of this is in Slovakia, where up to $74 \%$ of emergency room attendances were due to lack of available alternative primary care services [4]. Further to this, in the United Kingdom (UK), the National Health Service (NHS) reported that 18 million general practitioner (GP) appointments and 2.1 million emergency department (ED) visits could have been treated at a community pharmacist and would have saved the health service $£ 850$ million in 2017 alone [5]. The paediatric population in particular have contributed to the rise in ED attendances with the UK seeing an increase in attendances of $28 \%$ from 1999 to 2010 [6]. A large part of this was attributed to the failure of other primary care services in dealing with children that had minor illnesses [6]. There is an opportunity for community pharmacists to redefine their role in the management of childhood illness. They can be the first port of call for illnesses and alleviate the burden of treating non-severe pediatric presentations in other over-stretched primary care facilities [7].

A number of pharmacists in Europe provide services such as routine vaccinations, chronic disease management, smoking cessation, early screening, and testing of disease [1,2]. In Belgium for example, asthma patients prescribed inhaled corticosteroids were given two follow up appointments with a community pharmacist [8]. This pilot programme was shown to benefit up to 36,000 patients, with the service potentially expanding to other chronic conditions [8]. In the UK, 1.1 million children suffer from asthma, with the NHS spending over $£ 1$ billion on the disease annually [9]. With the 
condition being so manageable in the community setting, it is surprising that community pharmacists do not deal with a greater number of cases to prevent hospital admissions. Another example is in Ireland where over 50,000 patients (a tenth of people vaccinated) were given the flu vaccine by community pharmacists in 2014 [1,2]. In 2015, owing to the success of the scheme, the pharmacist remit was increased to include pneumococcal and shingles vaccines as well [10]. Children are the most common recipients of such vaccines and therefore, it is important to understand why a community pharmacist does not manage more of these vaccinations for children across Europe.

This literature review aims to understand how community pharmacy is currently being utilised by children, young people, and parents across Europe. Furthermore, it will possibly give insight into the current role of the community pharmacist in paediatric treatment, and how this role might change in the future.

\section{Materials and Methods}

The researchers, with the assistance of the librarian, developed appropriate search parameters and identified the most relevant databases for the review, to be conducted over two weeks in December 2017. The researchers looked for data published between January 2000 and December 2017. An extensive exploratory search was performed and the literature was thoroughly assessed and synthesised in order to generate conclusions and consider future steps.

Electronic databases were searched including PubMed, EMBASE, OVID, and HMIC (for grey literature), with each one being thoroughly searched using as many permutations of the following key words: "community pharmacy", "community pharmacist", "pharmacy", "pharmacist", "children", "paediatric", "parent", "carer", "over-the-counter", and "Europe". The databases were searched by combining Boolean logic with truncation marks to generate a comprehensive set of literature. The initial literature was then subject to the specific inclusion/exclusion criteria seen in Table 1 to identify results that were in line with the objectives of the study. Once articles were obtained through database searching, the references of these articles were then screened to ensure that no relevant literature was missed from the databases. A handful of relevant articles were identified through this method, in addition to the ones found via databases. Figure 1 provides an in-depth view of how the literature was screened and selected for synthesis in the form of a narrative review, through a PRISMA flowchart [11]. It should be noted that all the studies included in the synthesis were screened individually and collectively for publication bias and selective reporting and this is reported in the results section below.

Table 1. Inclusion and exclusion criteria for the literature at each stage of the research.

\begin{tabular}{|c|c|c|}
\hline Inclusion Criteria & Exclusion Criteria & Justification \\
\hline \multicolumn{3}{|l|}{ At search string level: } \\
\hline $\begin{array}{l}\text { Papers published between January } \\
2000 \text { and December } 2017\end{array}$ & & $\begin{array}{l}\text { The role of community pharmacists compared to } \\
\text { present day use may be significantly different }\end{array}$ \\
\hline Any article type & & This allows for a comprehensive review \\
\hline Full paper available & & $\begin{array}{l}\text { The full paper needs to be analysed in order for } \\
\text { the review to be robust }\end{array}$ \\
\hline \multicolumn{3}{|l|}{ At title/abstract level: } \\
\hline & $\begin{array}{l}\text { Paper does not specifically relate to use of } \\
\text { community pharmacy by children }\end{array}$ & $\begin{array}{l}\text { This literature review aimed to study the } \\
\text { utilisation of community pharmacy by paediatric } \\
\text { populations ( } 0-18 \text { years) in Europe }\end{array}$ \\
\hline English language paper & & $\begin{array}{l}\text { The resources were not sufficient to fully } \\
\text { translate papers }\end{array}$ \\
\hline Europe & & $\begin{array}{l}\text { This literature review aimed to study the } \\
\text { utilisation of community pharmacy by paediatric } \\
\text { populations ( } 0-18 \text { years) in Europe }\end{array}$ \\
\hline
\end{tabular}


Table 1. Cont.

\begin{tabular}{lll}
\hline \multicolumn{1}{c}{ Inclusion Criteria } & Exclusion Criteria & \multicolumn{1}{c}{ Justification } \\
\hline At full-text level: & & These articles are relevant to the study \\
\hline $\begin{array}{l}\text { Paper analyses utilisation of } \\
\text { community pharmacy by children }\end{array}$ & $\begin{array}{l}\text { Paper only mentions community } \\
\text { pharmacy as the location of a study }\end{array}$ & $\begin{array}{l}\text { This study aims to explore the utilization of } \\
\text { community pharmacies as a primary care service }\end{array}$ \\
\hline
\end{tabular}

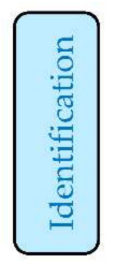

Records identified through database searching

$(\mathrm{n}=7864)$
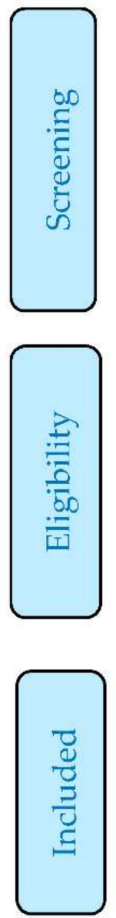

Additional records identified through other sources $(n=56)$

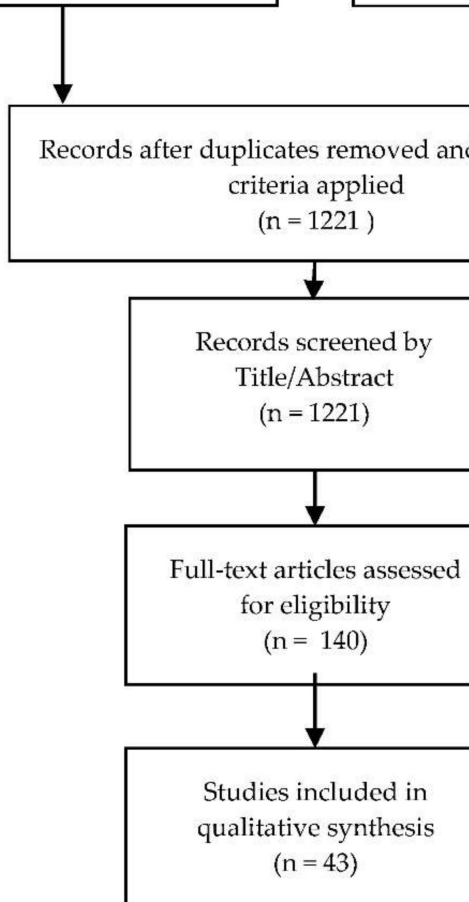

Figure 1. PRISMA flowchart [11] of how the literature was filtered to end up with the relevant articles for synthesis.

\section{Results}

Table 2 below demonstrates the number of studies from each country that were included in the synthesis.

In total, 43 studies were included in the synthesis as shown in the tables and PRISMA flowchart above. These studies demonstrated no clear publication bias or selective reporting. Non-English language studies $(n=187)$ were excluded due to translation resource restrictions. Table 3 gives an overview of all the results included, showing the type of study conducted as well as the key findings. 
Table 2. Number of studies included in synthesis stratified by country.

\begin{tabular}{cc}
\hline Country & Number of Studies Included in Synthesis \\
\hline United Kingdom (England, Scotland, Wales, Northern Ireland) & 19 \\
Sweden & 5 \\
Netherlands & 4 \\
France & 4 \\
Germany & 3 \\
Finland & 2 \\
Greece & 1 \\
Iceland & 1 \\
Belgium & 1 \\
Spain & 1 \\
Italy & 1 \\
Croatia & 1 \\
\hline
\end{tabular}

Table 3. Description of the synthesized studies.

\begin{tabular}{|c|c|c|c|c|}
\hline Reference as in Text & AuthorNo (Year) & Type of Paper/Study & Population Size & Main Study Finding \\
\hline [12] & Hammond (2004) & $\begin{array}{l}\text { Cross-sectional } \\
\text { questionnaire-based study }\end{array}$ & 3984 & $\begin{array}{l}\text { Pharmacists are a good source of } \\
\text { information for unwell children }\end{array}$ \\
\hline [13] & Hodgson (2004) & $\begin{array}{l}\text { Cross-sectional } \\
\text { questionnaire-based study }\end{array}$ & 85 & $\begin{array}{l}87 \% \text { of mothers find pharmacist } \\
\text { advice for sick children helpful }\end{array}$ \\
\hline [14] & Gray (2011) & $\begin{array}{l}\text { Cross-sectional mixed } \\
\text { methods study }\end{array}$ & $\begin{array}{l}134 \text { questionnaires, } \\
39 \text { interviews }\end{array}$ & $\begin{array}{l}82 \% \text { of parents find pharmacist advice } \\
\text { somewhat helpful } \\
\text { regarding medication }\end{array}$ \\
\hline [15] & Bamford (2015) & $\begin{array}{l}\text { Grey literature } \\
\text { (Charity report) }\end{array}$ & Not applicable & $\begin{array}{l}\text { Parents prioritise other information } \\
\text { sources over pharmacists }\end{array}$ \\
\hline [16] & Holappa (2012) & $\begin{array}{c}\text { Cross-sectional } \\
\text { questionnaire-based study }\end{array}$ & 4020 & $\begin{array}{l}44 \% \text { of parents seek pharmacist } \\
\text { advice for their sick children }\end{array}$ \\
\hline [17] & Gray (2017) & $\begin{array}{l}\text { Cross-sectional mixed } \\
\text { methods study }\end{array}$ & Not provided & $\begin{array}{l}\text { Most parents prefer receiving written } \\
(50 \%) \text { or spoken }(29 \%) \text { advice } \\
\text { from pharmacists }\end{array}$ \\
\hline [18] & Plachouras (2010) & $\begin{array}{l}\text { Cross-sectional } \\
\text { questionnaire-based study }\end{array}$ & 174 & $\begin{array}{l}\text { Inappropriate dispensing of } \\
\text { antibiotics by pharmacists possibly } \\
\text { led to widespread antibiotic resistance }\end{array}$ \\
\hline [19] & Stakenborg (2016) & $\begin{array}{l}\text { Cross-sectional focus } \\
\text { group-based study }\end{array}$ & 24 & $\begin{array}{l}\text { Parents trust their own knowledge } \\
\text { more than advice from pharmacists }\end{array}$ \\
\hline [20] & Gidman (2014) & $\begin{array}{l}\text { Cross-sectional focus } \\
\text { group-based study }\end{array}$ & 26 & $\begin{array}{l}\text { Parents did not want to bring children } \\
\text { to pharmacies due to presence of } \\
\text { substance misuse patients in the clinic }\end{array}$ \\
\hline [21] & Parsons (2013) & $\begin{array}{l}\text { Cross-sectional } \\
\text { questionnaire-based study }\end{array}$ & 99 & $\begin{array}{l}\text { Parents found that pharmacies lack } \\
\text { privacy compared to other primary } \\
\text { care services }\end{array}$ \\
\hline [22] & Guegan (2010) & Literature review & Not provided & $\begin{array}{l}\text { Pharmacists have a trusted } \\
\text { relationship with young patients } \\
\text { formed over multiple encounters }\end{array}$ \\
\hline [23] & $\begin{array}{l}\text { Karamanidou } \\
\text { (2016) }\end{array}$ & $\begin{array}{l}\text { Cross-sectional } \\
\text { interview-based study }\end{array}$ & 15 & $\begin{array}{l}\text { Expanded role for pharmacists in oral } \\
\text { contraceptive pill (OCP) provision } \\
\text { and HPV vaccine }\end{array}$ \\
\hline [24] & Terry (2016) & $\begin{array}{c}\text { Cross-sectional } \\
\text { observational study }\end{array}$ & 1623 & $\begin{array}{l}9 \% \text { of ED attendances could have } \\
\text { been dealt with in pharmacies }\end{array}$ \\
\hline [25] & Carr (2007) & $\begin{array}{l}\text { Pre-post interventional } \\
\text { pilot study }\end{array}$ & 50 & $\begin{array}{l}\text { Effective example of pharmacist led } \\
\text { intervention in childhood eczema }\end{array}$ \\
\hline [26] & Jacome (2003) & $\begin{array}{l}\text { Pre-post interventional } \\
\text { pilot study }\end{array}$ & 164 & $\begin{array}{l}\text { Effective example of pharmacist-led } \\
\text { intervention in childhood asthma }\end{array}$ \\
\hline [27] & Gay (2006) & Randomised control trial & 100 & $\begin{array}{l}\text { Ineffective example of pharmacist-led } \\
\text { intervention for Type } 1 \text { Diabetes }\end{array}$ \\
\hline [28] & Koster (2015) & $\begin{array}{l}\text { Cross-sectional } \\
\text { interview-based study }\end{array}$ & 170 & $\begin{array}{l}\text { Regular attendance of children when } \\
\text { collecting medication can improve } \\
\text { medication adherence }\end{array}$ \\
\hline [29] & Terry (2012) & Literature review & 24 references & $\begin{array}{l}\text { Increasing the communication } \\
\text { between pharmacies and other } \\
\text { primary care interfaces }\end{array}$ \\
\hline [30] & $\begin{array}{l}\text { de Jong-van den } \\
\text { berg (2008) }\end{array}$ & $\begin{array}{l}\text { Explorative } \\
\text { comparative study }\end{array}$ & Not provided & $\begin{array}{l}\text { Effective example of pharmacist-led } \\
\text { intervention in the reduction of } \\
\text { neural tube defects (NTDs) }\end{array}$ \\
\hline
\end{tabular}


Table 3. Cont

\begin{tabular}{|c|c|c|c|c|}
\hline Reference as in Text & AuthorNo (Year) & Type of Paper/Study & Population Size & Main Study Finding \\
\hline [31] & Deacon (2011) & Statistics report (Epilepsy) & Not applicable & Incidence of epilepsy in children \\
\hline [32] & Bilbow (2016) & $\begin{array}{l}\text { Grey Literature } \\
\text { (Charity report) }\end{array}$ & Not applicable & $\begin{array}{l}\text { Incidence of attention deficit } \\
\text { hyperactivity disorder (ADHD) } \\
\text { in children }\end{array}$ \\
\hline [33] & Perucca (2005) & Literature review & 55 references & $\begin{array}{l}\text { Medications for ADHD and epilepsy } \\
\text { have a high rate of adverse events }\end{array}$ \\
\hline [34] & Tobaiqy (2010) & $\begin{array}{c}\text { Cross-sectional } \\
\text { questionnaire-based } \\
\text { pilot study }\end{array}$ & 72 & $\begin{array}{l}\text { Exploring wider pharmacist } \\
\text { involvement in the UK Yellow } \\
\text { Card scheme }\end{array}$ \\
\hline [35] & Stewart (2005) & $\begin{array}{c}\text { Prospective } \\
\text { questionnaire-based study }\end{array}$ & 267 & $\begin{array}{l}\text { The pharmacist as a useful resource } \\
\text { for therapeutic drug monitoring }\end{array}$ \\
\hline [36] & Aston (2017) & $\begin{array}{l}\text { Cross-sectional } \\
\text { questionnaire-based study }\end{array}$ & 76 & $\begin{array}{l}23.7 \% \text { of pharmacists performed } \\
\text { medicine use reviews (MURs) for } \\
\text { children's medication }\end{array}$ \\
\hline [37] & Liley (2016) & $\begin{array}{l}\text { Pre-post interventional } \\
\text { pilot study }\end{array}$ & 15 & $\begin{array}{l}\text { Increased use of MURs by } \\
\text { pharmacists seems to improve } \\
\text { children's asthma control }\end{array}$ \\
\hline [38] & Ylinen (2010) & $\begin{array}{c}\text { Cross-sectional } \\
\text { questionnaire-based study }\end{array}$ & 4032 & $\begin{array}{l}50 \% \text { of children use over-the-counter } \\
\text { (OTC) medication }\end{array}$ \\
\hline [39] & Clavenna (2009) & Retrospective cohort study & $1,542,203$ & $\begin{array}{l}48 \% \text { of children receive } 1 \text { drug } \\
\text { prescription a month }\end{array}$ \\
\hline [40] & Italia (2015) & Retrospective cohort study & 3013 & $\begin{array}{l}31.6 \% \text { of children used an OTC drug } \\
\text { in the last month }\end{array}$ \\
\hline$[41,42]$ & $\begin{array}{l}\text { Koelch (2008)/ } \\
\text { Du (2009) }\end{array}$ & Retrospective cohort study & 17,450 & $\begin{array}{l}30 \% \text { of prescription medications for } \\
\text { children were being used without } \\
\text { proper prescription }\end{array}$ \\
\hline$[43,44]$ & $\begin{array}{l}\text { Smith (2008)/ } \\
\text { Smith (2008) }\end{array}$ & $\begin{array}{l}\text { Systematic literature review } \\
\text { (searching for randomised } \\
\text { controlled trials) }\end{array}$ & 3492 & $\begin{array}{l}\text { The various causes of mortality from } \\
\text { children using cough medicines }\end{array}$ \\
\hline [45] & Holmstrom (2014) & $\begin{array}{c}\text { Cross-sectional } \\
\text { questionnaire-based study }\end{array}$ & 77 & $\begin{array}{l}\text { Careless and casual behavior of } \\
\text { children towards OTC use }\end{array}$ \\
\hline [46] & Stewart (2007) & $\begin{array}{c}\text { Prospective } \\
\text { questionnaire-based study }\end{array}$ & 482 & $\begin{array}{l}40 \% \text { of pharmacists prescribed drugs } \\
\text { off-label }\end{array}$ \\
\hline [47] & Mukkatash (2011) & $\begin{array}{c}\text { Cross-sectional } \\
\text { questionnaire-based study }\end{array}$ & 563 & $\begin{array}{l}\text { The need for clinical trials to change } \\
\text { paediatric formulations, to reduce } \\
\text { off-label prescribing }\end{array}$ \\
\hline [48] & Hanna (2016) & $\begin{array}{l}\text { Cross-sectional } \\
\text { questionnaire-based study }\end{array}$ & 90 & $\begin{array}{l}\text { Only } 77 \% \text { of pharmacists knew to use } \\
\text { an adrenaline auto-injector for food } \\
\text { anaphylaxis }\end{array}$ \\
\hline [49] & Raffin (2016) & $\begin{array}{c}\text { Cross-sectional } \\
\text { questionnaire-based study }\end{array}$ & 500 & $\begin{array}{l}\text { Pharmacist perpetuate } \\
\text { a corticosteroid phobia in } \\
\text { the population }\end{array}$ \\
\hline [50] & Rees (2017) & $\begin{array}{l}\text { Cross-sectional mixed } \\
\text { methods study }\end{array}$ & 2191 & $\begin{array}{l}\text { Medication errors occur at a much } \\
\text { higher rate in community pharmacies } \\
\text { than other primary care interfaces }\end{array}$ \\
\hline [51] & Bardage (2013) & $\begin{array}{l}\text { Cross-sectional } \\
\text { questionnaire-based study }\end{array}$ & 1098 & $\begin{array}{l}6 \% \text { of pharmacists provided } \\
\text { inappropriate medication to } \\
\text { febrile children }\end{array}$ \\
\hline [52] & $\begin{array}{l}\text { Lapeyre-Mestre } \\
\text { (2004) }\end{array}$ & $\begin{array}{l}\text { Cross-sectional } \\
\text { questionnaire-based study }\end{array}$ & 176 & $\begin{array}{l}12.9 \% \text { of pharmacists provided } \\
\text { contra-indicated medication } \\
\text { to children }\end{array}$ \\
\hline [53] & Venables (2015) & $\begin{array}{l}\text { Cross-sectional focus } \\
\text { group-based study }\end{array}$ & 4 & $\begin{array}{l}60 \% \text { of pharmacists were very } \\
\text { dependent on product monographs }\end{array}$ \\
\hline [54] & Driesen (2009) & $\begin{array}{l}\text { Cross-sectional } \\
\text { questionnaire-based study }\end{array}$ & 101 & $\begin{array}{l}\text { Only } 30 \% \text { of pharmacists prescribed } \\
\text { oral rehydration solution (ORS) to } \\
\text { children with severe diarrhoea }\end{array}$ \\
\hline
\end{tabular}

The results are described by theme.

\subsection{Perceptions}

\subsubsection{Parental Perception}

Pharmacists are regularly compared by parents, to other sources of information about medication [12]. A UK study found that $87 \%$ of the time, mothers report such advice in dealing with minor illness in 
children, to be 'helpful' in managing the problem [13]. Another stated that $82 \%$ of parents reported that they have received 'very helpful' or 'helpful' advice from pharmacists regarding non-prescription medications, while $90 \%$ of the advice given had been fully understood by parents [14].

However, there are still variable levels of public trust in pharmacy services. Parents prioritise health information from the Internet and GPs over and above that given by pharmacists [15]. A study in Finland showed that only $44 \%$ of parents sought advice on treating their ill children from pharmacists compared to $70 \%$ who would seek a physician's advice [16]. If parents were to receive advice from health care professionals however, they preferred receiving written advice from a pharmacist or doctor (50\%), or spoken advice from a pharmacist (29\%) [17].

Parents identified various reasons for not trusting community pharmacist advice. In Greece, parents were hesitant to utilise pharmacists because of the lackadaisical attitude to antibiotic sale without prescription, possibly leading to wide scale resistance and adverse events [18]. A separate study in Netherlands indicated that parents did not trust explanations of doses and administration of drugs from a pharmacist, instead trusting their own limited knowledge more [19]. In addition to this, UK parents felt that pharmacists simply 'lacked adequate knowledge' specifically for their children [12].

Furthermore, the setting of the actual pharmacy may have an important effect on perception of the service. Parents felt that having substance users loitering in pharmacies, while awaiting harm reduction services and advice, was extremely intimidating to both their children and themselves [20]. This complemented the results of a study across the UK, which indicated that parents of young children found that pharmacies 'lacked privacy' that may otherwise be found at other primary care interfaces [21].

\subsubsection{Young People}

Children and young people across Europe have their own opinions on community pharmacists. A 2014 study of over 4000 adolescents across France, Germany, Portugal, and the UK demonstrated that pharmacists are more highly trusted by this age group than any other age group [15]. This notion was further confirmed by a UK trial of pharmacy-based OCP provision [21]. Following the trial, a staggering $97 \%$ of adolescent girls reporting being 'very comfortable' or 'comfortable' in discussing contraception with a pharmacist, while $87.5 \%$ were satisfied with the service they received [21]. In fact, owing to the trusted relationship that pharmacists are likely to share with patients from repeat encounters [22], they argue that they should have an expanded role in administering HPV vaccines and giving OCP to adolescent girls [23].

\subsection{Potential Opportunities}

The literature identified several opportunities for pharmacists to deal with paediatric patients in various capacities.

\subsubsection{Acute Minor Illness}

The literature identifies the possibility of an increased role for pharmacists in dealing with acutely unwell children. One UK study showed that $9 \%$ of ED attendees were appropriate for treatment by community pharmacists instead [24]. Similarly, $15 \%$ of consultations with children attending general practices in the UK were deemed unnecessary as opposed to just $6 \%$ in adults [12]. These studies demonstrate an opportunity for the diversion of children from other primary care services to the community pharmacy.

\subsubsection{Chronic Disease}

Several studies highlighted the important role pharmacists could play in the management of chronic paediatric disease. Pharmacist intervention in childhood eczema was trialled in a study, resulting in a statistically significant reduction in the severity of all symptoms. Furthermore, $78 \%$ of parents found the advice given to be 'very helpful' or 'helpful', with a marked increase in effective emollient use [25]. A similar pharmacist-led intervention was trialled in Spain, with the aim of 
improving childhood asthma control [26]. The intervention led to an increase in quality of life measures by 0.81 points, as well as a significant reduction in poorly controlled asthma by 1.15 points compared to the control group [26]. However, in the control of type 1 diabetes in children, patients in the pharmacist-led intervention group were shown to have no significant difference in their $\mathrm{HbA} 1 \mathrm{c}$ compared to the control group [27]. Researchers suggested that this was due to poor follow-up attendance among the intervention group [27].

In order for pharmacists to have a truly meaningful impact on the management of chronic conditions, they need to foster stronger relationships with adolescents [17]. Authors argue that if children were present at medication collection, pharmacists could then make them feel comfortable with the information being provided and the setting [17]. Other literature also agrees that regular attendance of children at medication collection could improve adherence [28]. This combined with counselling of the children and distribution of relevant leaflets, can help reduce the rate of medication non-adherence in this population group [28]. Specifically for adolescents, it was found that they could be counselled on the interaction of medications with alcohol or other drugs, as this is both relevant to their lifestyle and can help build rapport with a 'non-judgmental' pharmacist [14].

Furthermore, to successfully manage chronic conditions in children, more could be done to facilitate communications between the hospital, community pharmacy, and primary care in order to improve continuity of care for children and parents [29]. This is especially because of the lack of information sharing between these three interfaces of care, regarding paediatric medication [29]. To ensure that parents remain committed and not frustrated with the care of their unwell child, there must be a greater deal of cohesion between the services [29].

\subsubsection{Pregnancy and Antenatal Care}

A study in the Netherlands set up a new, pharmacist-led service for women trying to conceive, which looked to increase the awareness of folic acid use in pregnancy. Following the programme, it was seen that the prevalence of NTD almost halved in just a year while $93 \%$ of the community approved of the initiative [30].

\subsubsection{Pharmacovigilance}

The literature identified the potential use of pharmacies for enhanced pharmacovigilance. The incidence of epilepsy in children under 18 is approximately $0.5 \%$ [31], while ADHD incidence in school-aged children is about $5 \%$ [32]. Management of these conditions involves medication that has a high rate of adverse events [33] and so there is a need here for medication monitoring especially in young children. Two separate studies in Scotland recommended wider pharmacist involvement in the UK Yellow Card scheme (YCS) for adverse events, to ensure that the proper side effect profiles of the drugs can be documented $[34,35]$. If uptake were to be increased in a sufficient number of pharmacists, this could be a very valuable source of adverse drug reaction reporting, as pharmacists are frequently the first port of call for medication issues [34,35].

Pharmacists could also improve their role in pharmacovigilance through increasing the number of medicines use reviews (MURs) performed on medications for chronic conditions. One English study found the level of pharmacists engaging in MURs to be as low as $23.7 \%$ when monitoring the experience of young children on medication for chronic conditions [36]. The importance was highlighted in a related UK trial study, which found an increase in the average asthma control by seven points when MURs and asthma counselling were routinely offered by pharmacists [37]. The increase in MURs however, would necessitate increased reimbursement and further training in order for pharmacists to be confident in carrying out such reviews [36].

\subsubsection{OTC Drug Use in Children}

There are varying levels of OTC medicine usage across Europe. Almost 50\% of Finnish children use OTC self-medication, especially for treating asthma and fevers [38]. In an Italian study of over 
1.5 million children and adolescents, it was reported that a similar proportion (48\%) of children received at least one drug prescription every month [39]. Germany seemed to have a lower reported use of OTC drug use with only $31.6 \%$ of 15 year olds having consumed them in the last month [40]. However, it was found that $30 \%$ of all medication purchased by children in Germany, especially sedatives, were being used without prescription [41]. The use of OTC prescriptions in German children was attributed to a variety of factors including greater maternal education, families with higher household incomes, non-immigrants, and children that had long-term illness [42]. In the UK, it was found that there were 24 million episodes of cough medication being used in children [43] even though a Cochrane review found no good evidence for or against the effectiveness of these medications [44]. Furthermore, the 59 deaths attributed to cough medicines were related to accidental exposure (22\%), intentional overdose $(6 \%)$, and medication error $(16 \%)$ with the manner of overdose undetermined in the remaining $56 \%$ of cases [43]. Children are not being educated on the risks of overusing OTC medication with a Swedish study indicating that adolescent behaviour towards OTC was 'careless and casual' [45].

\subsubsection{Off-Label Drug Use}

The literature gave insight into the use of off-label drugs by pharmacists, with a UK study showing that $40 \%$ of pharmacists had prescribed drugs in this way [46]. Pharmacists certainly had the highest level of concern (86\%) among health care professionals, regarding off-label prescribing, with a majority arguing the need for urgent clinical trials to correct paediatric formulations [47]. They are willing to be flexible in prescribing appropriately for children although they mostly believed (66\%) that they had a responsibility to warn parents about potential problems with off-label prescribing [46].

\subsection{Further Training Needs}

The literature reviewed the current practice of community pharmacists suggesting some possible improvements to ensure the standards of care were being met for children and young people.

\subsubsection{Emergency Setting}

Disease or treatment specific training in community pharmacists has been shown to be effective. One such example was in a study of pharmacist perceptions to anaphylaxis. It was found that $77 \%$ of pharmacists were aware of adrenaline auto-injector use as the first line management of paediatric food allergy anaphylaxis [48], while only $7 \%$ were confident in using the device. This suggests that further training in emergency scenarios would be a useful addition to the knowledge base possessed by pharmacists.

\subsubsection{Community Pharmacists as Medication Advisers}

The literature described how community pharmacists were averse to using corticosteroids in the management of chronic asthma in children. Due to their own beliefs and their position as trusted medication advisers, they dissuaded parents from using corticosteroids in asthma management leading to what one author described as a nationwide 'corticosteroid phobia' in France [48]. Improved training of pharmacists in asthma care, especially around appropriate corticosteroid usage, is certainly needed to avoid over emphasis of the 'dangerous' side effects [49].

\subsubsection{Drug Safety}

One of the issues that was evident in the literature review was the prevalence of safety incidents that occurred at community pharmacies. A study of about 3000 safety incidents in England and Wales alone revealed that medication errors occurred at a much higher rate in community pharmacies than general practice, dental surgeries, or even community nursing services [50]. Authors argued the case 
for a barcoding system that could reduce error potential from manual entry and act as a further safety check [50].

Other than technical errors in prescribing, pharmacists occasionally make mistakes in the choice of medication for acutely unwell children. A Swedish 'mystery-shopper' study indicated that pharmacists provided inappropriate medication to feverish children, up to $6 \%$ of the time [51] and a French study found that pharmacists were offering strictly contra-indicated drugs to children $12.9 \%$ of the time [52].

A Dutch study argued that these errors might be the result of a low use (14\%) of up-to-date literature by pharmacists, while a large proportion of pharmacists $(60 \%)$ were extremely dependent on the product monographs [53]. However, the poor choice of medication may also be explained by the history taking of pharmacists in acutely unwell children. A Belgian study showed that $84 \%$ of pharmacists did not enquire about dehydration symptoms in an eight-month-old with acute diarrhoea, while only 30\% proceeded to prescribe an ORS [54]. Giving them the benefit of the doubt, some literature suggests that pharmacists' knowledge may not be applied adequately due to a lack of questioning, poor communication skills, and parental pressures [52]. One possible solution to this is increasing the frequency, and improving the quality, of training received by pharmacists, alongside their routine practice [50].

\section{Discussion}

This is the first major narrative review of community pharmacy use by parents, children, and young people in Europe. Overall, parents and young people have a high regard for local community pharmacists who are considered as authoritative sources of information and advice particularly for minor illness, chronic disease management, and medication review. Issues of communication with primary care and hospital pharmacy providers remain an area for further quality improvement to ensure both timely and consistent advice as well as safe prescribing. We have found that adolescents, in particular, value the confidentiality aspects of community pharmacists especially in relation to sexual health and vaccination advice. On the other hand, the high use of OTC products and off-label drugs by this age group is of concern and presents both opportunities for health education and a greater attention to pharmacovigilance.

Despite the fact that pharmacists may not be necessarily seen as first points of contact when compared to general practitioners or the internet from a parental perspective, there is potential for additional training and accreditation to support the needs of this age group. This would allow a broadening of the scope of services offered in a suitable physical environment. Infants and young children's health is very much determined by the health of the mother in pregnancy and pharmacies can provide a valuable service in identification of at risk women and optimization of infant health. This could be done through ensuring nutritional supplementation throughout pregnancy like in the Netherlands where there was a substantial reduction in the incidence of neural tube defects found in the intervention group [30]. With appropriate training and accreditation, many more services could be offered by community pharmacists including increased access to smoking cessation, weight management services, and drug or alcohol reduction services. These in turn could have a considerable impact on maternal and infant health. We hope to soon report on a paediatric-pharmacy joint training initiative scheme currently being piloted in three areas of London, which might provide a useful model for other countries.

\section{Conclusions}

Community pharmacists in Europe are an untapped resource for children, young people and their parents and further recognition of their important role could usefully support the demands made on other primary care services. 


\section{Limitations}

There are a few limitations of the review that may have affected the results obtained. The main limitation was that only English language studies were included in the research due to the limited resources. Following on from this, only a small number of English language research articles were published in other EU countries. Of the articles used in the synthesis, 18 were papers from the UK, while the remainder originated from 11 different countries. This represents a bias in the results, as across countries, there are likely to be national and cultural differences with regards to community pharmacy practice. Inclusion of foreign language papers may have revealed pertinent work from the other countries that may have informed future practice and training recommendations. Furthermore, the results were screened by just one researcher and therefore, some relevant results may have been excluded based on the researchers' own selection bias of what was included in the synthesis. To mitigate this, any uncertainty was discussed by both authors who then agreed upon inclusion/exclusion. Moreover, time and resource limitations meant that the researchers were not able to obtain and confirm additional data from individual study investigators.

\section{Further Research}

This research could be used to support a periodic EU survey of parents and young people, which would ensure a more representative sampling of countries. Studies are clearly needed on the effectiveness of any pharmacy training initiatives which enhance safe prescribing practices or are designed to divert minor illnesses from emergency departments with appropriate safety netting.

Author Contributions: M.B. originated the idea and prepared the first draft while A.M. completed a systematic review, compiled the results, and refined the manuscript.

Acknowledgments: This project has received funding for dissemination from the European Union's Horizon 2020 research and innovation programme (MOCHA), grant agreement no. 634201.

Conflicts of Interest: M.B. is funded in part by the National Institute for Health Research (NIHR) under the Collaborations for Leadership in Applied Health Research and Care (CLAHRC) programme for North West London. The views expressed in this publication are those of the author(s) and not necessarily those of the NHS, the NIHR, or the Department of Health.

\section{References}

1. Svarcaite, J. Overview of Community Pharmacy Services in Europe. 2016. Available online: https://www. oecd.org/els/health-systems/Item-2b-Overview-Community-Pharmacy-Services-Svarcaite\%20.pdf (accessed on 18 December 2017).

2. OECD; EU. Health at a Glance: Europe 2016, 4th ed.; Organisation for Economic Co-Operation and Development: Paris, France, 2016.

3. EU. Living in the EU. 2017. Available online: https://europa.eu/european-union/about-eu/figures/living en (accessed on 25 December 2017).

4. OECD; European Observatory on Health Systems. State of Health in the EU. Slovak Republic: Country Health Profile 2017; OECD: Paris, France; European Observatory on Health Systems: Brussels, Belgium, 2017.

5. Association, P. NHS Urges Parents to Use Pharmacies for Children's Illnesses. The Guardian Online 2018. Available online: https: / read.oecd-ilibrary.org/social-issues-migration-health/slovak-republic-countryhealth-profile-2017_9789264283541-en\#page1 (accessed on 12 February 2018).

6. Gill, P.; Goldacre, M.J.; Mant, D.; Heneghan, C.; Thomson, A.; Seagroatt, V.; Harnden, A. Increase in emergency admissions to hospital for children aged under 15 in England, 1999-2010: National database analysis. Arch. Dis. Child. 2013, 98, 328-334. [CrossRef] [PubMed]

7. Blair, M.; Oligbu, G.; EI Tokhy, O.; Levitan, M.; Goldstone, P.; Lathlean, P. G69 how do community pharmacies support children with minor illness. Arch. Dis. Child. 2018, 103, A28-A29.

8. Fraeyman, J.; Foulon, V.; Mehuys, E.; Boussery, K.; Saevels, J.; De Vriese, C.; Dalleur, O.; Housiaux, M.; Steurbaut, S.; Naegels, M.; et al. Evaluating the implementation fidelity of New Medicines Service for asthma patients in community pharmacists in Belgium. Res. Soc. Adm. Pharm. 2017, 13, 98-108. [CrossRef] [PubMed] 
9. Asthma UK. Asthma Facts and Statistics. 2016. Available online: https://www.asthma.org.uk/about/ media/facts-and-statistics / (accessed on 25 December 2017).

10. Pharmaceutical Society of Ireland. Guidance on the Provision of Vaccination Services by Pharmacists in Retail Pharmacy Businesses; Pharmaceutical Society of Ireland: Dublin, Ireland, 2016; p. 4.

11. Liberati, A.; Altman, D.G.; Tetzlaff, J.; Mulrow, C.; Gotzsche, P.C.; Ioannidis, J.P.A.; Clarke, M.; Devereaux, P.J.; Kleijnen, J.; Moher, D. The PRISMA statement for reporting systematic reviews and meta-analyses of studies that evaluate health care interventions: Explanation and elaboration. PLoS Med. 2009, 6, e1000100. [CrossRef] [PubMed]

12. Hammond, T.; Clatworthy, J.; Horne, R. Patients' use of GPs and community pharmacists in minor illness: A cross-sectional questionnaire-based study. Fam. Pract. 2004, 21, 146-149. [CrossRef] [PubMed]

13. Hodgson, C.; Wong, I. What do mothers of young children think of community pharmacists? A descriptive survey. J. Fam. Health Care 2004, 14, 73-74. [PubMed]

14. Gray, N.J.; Boardman, H.F.; Symonds, B.S. Information sources used by parents buying non-prescription medicines in pharmacies for preschool children. Int. J. Clin. Pharm. 2011, 33, 842-848. [CrossRef] [PubMed]

15. Bamford, S.; Kneale, D.; Wilson, J.; Watson, J. A New Journey to Health-Health Infrormation Seeking Behaviour Across the Ages; International Longevity Centre: London, UK, 2015; p. 1.

16. Holappa, M.; Ahonen, R.; Vainio, K.; Hameen-Anttila, K. Information sources used by parents to learn about medications they are giving their children. Res. Soc. Adm. Pharm. 2012, 8, 579-584. [CrossRef] [PubMed]

17. Gray, N.J.; Shaw, K.L.; Smith, F.J.; Burton, J.; Prescott, J.; Roberts, R.; Terry, D.; McDonagh, J.E. The Role of Pharmacists in Caring for Young People with Chronic Illness. J. Adolesc. Health 2017, 60, 219-225. [CrossRef] [PubMed]

18. Plachouras, D.; Kavatha, D.; Antoniadou, A.; Giannitsioti, E.; Poulakou, G.; Kanellakopoulou, K.; Giamarellou, H. Dispensing of antibiotics without prescription in Greece, 2008: Another link in the antibiotic resistance chain. Euro Surveill 2010, 18, 15.

19. Stakenborg, J.P.; de Bont, E.G.; Peetoom, K.K.; Nelissen-Vrancken, M.H.; Cals, J.W. Medication management of febrile children: A qualitative study on pharmacy employees' experiences. Int. J. Clin. Pharm. 2016, 38, 1200-1209. [CrossRef] [PubMed]

20. Gidman, W.; Coomber, R. Contested space in the pharmacy: Public attitudes to pharmacy harm reduction services in the West of Scotland. Res. Soc. Adm. Pharm. 2014, 10, 576-587. [CrossRef] [PubMed]

21. Parsons, J.; Adams, C.; Aziz, N.; Holmes, J.; Jawad, R.; Whittlesea, C. Evaluation of a community pharmacy delivered oral contraception service. J. Fam. Plan. Reprod. Health Care 2013, 39, 97-101. [CrossRef] [PubMed]

22. Guegan, E. Infection prevention and management by community pharmacists. J. Infect. Prev. 2010, 11, 106-109. [CrossRef]

23. Karamanidou, C.; Dimopoulos, K. Greek health professionals' perceptions of the HPV vaccine, state policy recommendations and their own role with regards to communication of relevant health information. BMC Public Health 2016, 16, 467. [CrossRef] [PubMed]

24. Terry, D.; Petridis, K.; Aiello, M.; Sinclair, A.; Huynh, C.; Mazard, L.; Ubhi, H.; Terry, A.; Hughes, E. The Potential for Pharmacists to Manage Children Attending Emergency Departments. Arch. Dis. Child. 2016, 101, e2. [CrossRef] [PubMed]

25. Carr, A.; Patel, R.; Jones, M.; Suleman, A. A pilot study of a community pharmacist intervention tp promote the effective use of emollients in childhood eczema. Pharm. J. 2007, 278, 319-322.

26. Jacome, J.; Inesta Garcia, A. Prospective study about the impact of a community pharmaceutical care service in patients with asthma. Rev. Esp. Salud Publica 2003, 77, 393-403.

27. Gay, C.L.; Chapuis, F.; Bendelac, N.; Tixier, F.; Treppoz, S.; Nicolino, M. Reinforced follow-up for children and adolescents with type 1 diabetes and inadequate glycaemic control: A randomized controlled trial intervention via the local pharmacist and telecare. Diabetes Metab. 2006, 32, 159-165. [CrossRef]

28. Koster, E.S.; Philbert, D.; Winters, N.A.; Bouvy, M.L. Medication adherence in adolescents in current practice: Community pharmacy staff's opinions. Int. J. Pharm. Pract. 2015, 23, 221-224. [CrossRef] [PubMed]

29. Terry, D.; Sinclair, A. Prescribing for children at the interfaces of care. Arch. Dis. Child. Educ. Pract. Ed. 2012, 97, 152-156. [CrossRef] [PubMed]

30. De Jong-van den Berg, L.T. Monitoring of the folic acid supplementation program in The Netherlands. Food Nutr. Bull. 2008, 29 (Suppl. 2), S210-S213. [CrossRef] [PubMed] 
31. Deacon, K. Epilepsy Prevalence, Incidence and Other Statistics; Epilepsy Foundation: Landover, MD, USA, 2011; p. 1.

32. Bilbow, A. ADHD: Paying Enough Attention; ADDISS: Middlesex, UK, 2016; p. 1.

33. Perucca, E.; Meador, K.J. Adverse effects of antiepileptic drugs. Acta Neurol. Scand. Suppl. 2005, 181, 30-35. [CrossRef] [PubMed]

34. Tobaiqy, M.; Stewart, D.; Helms, P.J.; Bond, C.; Lee, A.J.; Bateman, N.; McCaig, D.; McLay, J. A pilot study to evaluate a community pharmacy-based monitoring system to identify adverse drug reactions associated with paediatric medicines use. Eur. J. Clin. Pharmacol. 2010, 66, 627-632. [CrossRef] [PubMed]

35. Stewart, D.; Helms, P.; McCaig, D.; Bond, C.; McLay, J. Monitoring adverse drug reactions in children using community pharmacies: A pilot study. Br. J. Clin. Pharmacol. 2005, 59, 677-683. [CrossRef] [PubMed]

36. Aston, J.; Wilson, K.A.; Terry, D.R. Children/young people taking long-term medication: A survey of community pharmacists' experiences in England. Int. J. Pharm. Pract. 2017, 26, 104-110. [CrossRef] [PubMed]

37. Lilley, A. Assessing the Benefits that Community Pharmacies can have on Childhood Asthma Outcomes. Arch. Dis. Child. 2016, 101, e2. [CrossRef] [PubMed]

38. Ylinen, S.; Hameen-Anttila, K.; Sepponen, K.; Lindblad, A.K.; Ahonen, R. The use of prescription medicines and self-medication among children-A population-based study in Finland. Pharmacoepidemiol. Drug Saf. 2010, 19, 1000-1008. [CrossRef] [PubMed]

39. Clavenna, A.; Sequi, M.; Bortolotti, A.; Merlino, L.; Fortino, I.; Bonati, M. Determinants of the drug utilization profile in the paediatric population in Italy's Lombardy Region. Br. J. Clin. Pharmacol. 2009, 67, 565-571. [CrossRef] [PubMed]

40. Italia, S.; Brand, H.; Heinrich, J.; Berdel, D.; von Berg, A.; Wolfenstetter, S.B. Utilization of self-medication and prescription drugs among 15-year-old children from the German GINIplus birth cohort. Pharmacoepidemiol. Drug Saf. 2015, 24, 1133-1143. [CrossRef] [PubMed]

41. Koelch, M.; Prestel, A.; Singer, H.; Keller, F.; Fegert, J.M.; Schlack, R.; Hoelling, H.; Knopf, H. Psychotropic medication in children and adolescents in Germany: Prevalence, indications, and psychopathological patterns. J. Child Adolesc. Psychopharmacol. 2009, 19, 765-770. [CrossRef] [PubMed]

42. Du, Y.; Knopf, H. Self-medication among children and adolescents in Germany: Results of the National Health Survey for Children and Adolescents (KiGGS). Br. J. Clin. Pharmacol. 2009, 68, 599-608. [CrossRef] [PubMed]

43. Smith, S.M.; Henman, M.; Schroeder, K.; Fahey, T. Over-the-counter cough medicines in children: Neither safe or efficacious? Br. J. Gen. Pract. 2008, 58, 757-758. [CrossRef] [PubMed]

44. Smith, S.M.; Schroeder, K.; Fahey, T. Over-the-counter medications for acute cough in children and adults in ambulatory settings. Cochrane Database Syst. Rev. 2008, 23, CD001831. [CrossRef]

45. Holmstrom, I.K.; Bastholm-Rahmner, P.; Bernsten, C.; Roing, M.; Bjorkman, I. Swedish teenagers and over-the-counter analgesics-Responsible, casual or careless use. Res. Soc. Adm. Pharm. 2014, 10, 408-418. [CrossRef] [PubMed]

46. Stewart, D.; Rouf, A.; Snaith, A.; Elliott, K.; Helms, P.J.; McLay, J.S. Attitudes and experiences of community pharmacists towards paediatric off-label prescribing: A prospective survey. Br. J. Clin. Pharmacol. 2007, 64, 90-95. [CrossRef] [PubMed]

47. Mukattash, T.; Hawwa, A.F.; Trew, K.; McElnay, J.C. Healthcare professional experiences and attitudes on unlicensed/off-label paediatric prescribing and paediatric clinical trials. Eur. J. Clin. Pharmacol. 2011, 67, 449-461. [CrossRef] [PubMed]

48. Hanna, H.J.; Emmanuel, J.; Naim, S.; Umasunthar, T.; Boyle, R.J. Community healthcare professionals overestimate the risk of fatal anaphylaxis for food allergic children. Clin. Exp. Allergy 2016, 46, 1588-1595. [CrossRef] [PubMed]

49. Raffin, D.; Giraudeau, B.; Samimi, M.; Machet, L.; Pourrat, X.; Maruani, A. Corticosteroid Phobia Among Pharmacists Regarding Atopic Dermatitis in Children: A National French Survey. Acta Derm. Venereol. 2016, 96, 177-180. [CrossRef] [PubMed]

50. Rees, P.; Edwards, A.; Powell, C.; Hibbert, P.; Williams, H.; Makeham, M.; Carter, B.; Luff, D.; Parry, G.; Avery, A.; et al. Patient Safety Incidents Involving Sick Children in Primary Care in England and Wales: A Mixed Methods Analysis. PLoS Med. 2017, 14, e1002217. [CrossRef] [PubMed] 
51. Bardage, C.; Westerlund, T.; Barzi, S.; Bernsten, C. Non-prescription medicines for pain and fever-A comparison of recommendations and counseling from staff in pharmacy and general sales stores. Health Policy 2013, 110, 76-83. [CrossRef] [PubMed]

52. Lapeyre-Mestre, M.; Pin, M. Management of acute infantile diarrhoea: A study on community pharmacy counseling in the Midi-Pyrenees region. Arch. Pediatr. 2004, 11, 898-902. [CrossRef] [PubMed]

53. Venables, R.; Stirling, H.; Batchelor, H.; Marriott, J. Problems with oral formulations prescribed to children: A focus group study of healthcare professionals. Int. J. Clin. Pharm. 2015, 37, 1057-1067. [CrossRef] [PubMed]

54. Driesen, A.; Vandenplas, Y. How do pharmacists manage acute diarrhoea in an 8-month-old baby? A simulated client study. Int. J. Pharm. Pract. 2009, 17, 215-220. [CrossRef] [PubMed]

2018 by the authors. Licensee MDPI, Basel, Switzerland. This article is an open access article distributed under the terms and conditions of the Creative Commons Attribution (CC BY) license (http://creativecommons.org/licenses/by/4.0/). 